\title{
SAINT GREGORY THE ILLUMINATOR AND CANONS OF NICENE ECUMENICAL COUNCIL
}

\begin{abstract}
The Nicene Creed in the Armenian Apostolic Church is a stricter version of the Christian faith. Christian recites it as a confession of his faith. The article attempts to identify formulation origins of creed partly related with apostolic times. Next is presented, how in year 325 during the first ecumenical meeting convened in Nicaea the high-ranking fathers collected the items of Christian faith and gave the name of Nicene Creed or Creed. Gregory the Illuminator accepted the decisions of the Nicene creed and canonize that Creed in the Armenian Apostolic Church, however, unlike other Christian churches, add his own confession. In addition to that Creed, two more Creeds are canonized and stored in the Armenian Church. All of them express the nature and essence of God and Holy Trinity, which is the foundation and major axis of Christianity.
\end{abstract}

Keywords: St. Gregory the Illuminator, ecumenical meeting, "Nicene Creed", Church fathers, canonization, Creed, confession, nature of God, S. Trinity, major axis.

The Nicene Creed in the Armenian Apostolic Church is a profession of faith widely used in Christian liturgy. Christian recites it as a confession of faith. According to the tradition of Western Church Fathers the authors of the creed are 12 apostles, thus the formulation of belief was the armor of reputation of apostles. The Creed that is partly related to Apostolic times is still recited in the Armenian Church before baptism.The ancient trace of Apostolism dates back to the time of Jesus and the order given to his apostles.

"Therefore go and make disciples of all nations, baptizing them in the name of the Father and of the Son and of the Holy Spirit." (Astuac'ashunch 1994: 35)

Armenian Apostolic Church has kept and canonized that ancient creed which is used the beginning of baptism, after the "Renounce" when the priest,baptized person and those who are present say the following words turning to the East.

"We believe the Holy Trinity, the Father, the Son, and the Holy Spirit." (Shahe' arq. Atwe'mean 2001: 20)

In general the formulation of the Creed was developed by the Fathers of Church at the time when deviations were noticed in the church life, and it was an essential issue to keep the faith immaculate. In the first two centuries there were Jewish converts among Christians who found it difficult to accept the divinity of Christ and therefore the confession of St. Trinity. In the New Testament people who disavow Jesus Christ are mentioned. (Astuac'ashunch 1994: 330)

Apostle John in his first paper condemned those who denied the incarnation of Jesus Christ. 
"And who is he a liar but he that denieth that Jesus is the Christ." (Astuac'ashunch 1994: 321)

The spread of Christianity in the Roman Empire was a challenge for the apostles and their successors, because here Greek philosophy and culture were dominating. Their main mission was to keep the simplicity of the Gospel teaching avoiding the influence of philosophical thinking, which was widespread in religious communities. Fathers' motto has always remained Paul's famous words.

"Your faith unto a wise man, but by the power of God." (Astuac'ashunch 1994: 214)

Confessional issues and theological disputes were a a serious reason for emperors to invite Ecumenical Council.

The next stage of Christian Church history is linked to the convening of Ecumenical meetings, the discussion of theological issues and formulation of the Creed. Indeed, D century was a period of transition and that was its historical originality.

Several problems that needed final solutions were noted in religious, confessional and theological issues immediately after Christianity became a permissible religion. Issues such as monotheism,trinity, personification of Christ, atonement, transgression, salvation, consummation along with other religious matters were discussed during the Ecumenical meeting.

In parallel with it new doctrines appeared which not only spread quickly throughout Christian world within a short period, but also lead to confusion in church relations.Soon it was necessary to elaborate and coordinate the theology of Universal Christian Church according to the oracle of Gospel.

The peace of church was broken in the D-century because of the sermons of Arius priest who lived in Alexandria, Egypt. Arius denied the divine nature of Christ and jeopardized the entire Christian doctrine. Alexander Archbishop of Alexandria convened a local ecclesiastical meeting which rejected the doctine of Arius. He left Alexandria, but continued his preaching. (Kelli 1993: 54)

Seeing that the revolt gained momentum in the Christian Church, the Roman Emperor Constantine the Great convened the first ecumenical meeting in the city of Nicaea on May 20,325, which lasted until August 25. 318 high-ranking church fathers came to take part in the meeting. (Kartashev 1994: 21-22)

The primary consideration of the council was to discuss Arius' concepts and condemn his teaching ideas. According to Emperor's order Arius was exiled and expelled from the church. At the same time the members of the meeting collected the items of Christian faith within one original form,which was named Nicene Creed or Creed.Creed was accepted by all the bishops who participated in Ecumenical council, except two.

Saint Gregory the Illuminator was also invited to participate in Nicene Ecumenical council but he sent his son Bishop Aristakes instead. Aristakes attended the meeting and brought "The Creed" and the regulations with him to Armenia that were adopted during the meeting. Saint Gregory the Illuminator accepted the decisions of the Nicene creed and convented the Faith in the Armenian Apostolic Church, but unlike other Christian churches, added his confession which was based on the Holy Trinitarian creed adopted by the New Testament.

"As for us we shall glorify Him was before the ages, worshipping the Holy Trinity and the One Godhead, the Father, the Son and the Holy Spirit." (Shahe' arq. Atwe'mean 2001: 6)

The Armenian church still accepts and retains the sacred Creed and during the Holy Mass, when the Creed is pronounced, every time the priest repeats confession of Saint Gregory the Illuminato. 
The answer of Church Fathers for wrong teachings was always based on the teaching of Gospel and explanation of Apostolic Fathers.

Christian Church kept sacred the Creed of apostles that was transmitted as a behest in order to keep immaculate the entrusted Creed via the full power of Faith.

Until today, in order to warn believers of the church about the wrong teachings after the liturgy of the Nicene Creed in the Armenian church the trumpet repeats the statement of Nicene Patriarchs.

"As for those who say there was a time when the Son was not or there was a time when the Holy Spirit was not or that they came into being out of nothing or who say that the Son of God or the Holy Spirit be of different substance and that they be changeable or alterable, such doth the Catholic and Apostolic Church anathematize." (Shahe' arq. Atwe'mean 2001: 12)

Nicene council, which was convened for denying Arius delusion, didn't explain the essence of St. Trinity, but formulated the doctrine of Bible against those who denied the divinity of Jesus and eternity of St. Spirit. These were not only deviations of faith, but also attempts to examine, understand and explain the mystery of God's essence via huamn cognition.

The emperor and many of the participants thought that the Nicene Creed would establish solidarity in the life of Church in either religious or political sense, but in the Creed the explanations "Father coexistent" and "Begotten of Father" gave way to a lot of criticism, mainly because those explanations did not belong to the Evangelical vocabulary. (Abbe Duchesne 1950: 26)

Armenians have been very careful while using philosophical terms in faith expressions, even Saint Gregory the Illuminator did not want to use "Father Coexistent" explanation for Jesus that was accepted by the Fathers of Nicaea, and always kept the "Nature of the Father" form. In "Faitful Speeches" the author also uses the "One nature" explanation.

"We believe also in only One, Universal, Apostolic, and [Holy] Church; in one baptism in repentance, for the remission, and forgiveness of sins; and in the resurrection of the dead, in the everlasting judgement of souls and bodies, and the Kingdom of Heaven and in the everlasting life." (Kniq hawatoy 1914: 22)

The Nicene Creed was completed in 381 in Second Ecumenical meeting in Constantinople, when the doctrine of Makedon was condemned and for the Trinity "One deity, three people" formula was established. In fact, the Creed was supplemented with the part of St. Soul. (Kirakosyan 2007: 29-32)

The Nicene Creed consists of twelve parts and obliges to believe in St. Trinity, Jesus' redemptive mission, the Church, baptism, the resurrection of the dead, the kingdom of heaven and eternal life as well as Church Creed, whose main components are Union, apostolicity, holiness and communality. And although the Creed is considered to be eternal and immutable truth, it has been supplemented and modified by some churches.

The amendment, according to which St. Spirit proceeds from the Son of God (and not only God the Father), became one of the reasons of separation of Catholic and Orthodox Churches (Orthodoxy does not accept the amendment).

In fact, the Two Creeds that were developed and formulated in Christian churches belong to two traditions, one of which arose in Rome and the West, while another group in Eastern Churches. The Armenian Church canonized the Creed belonging to Eastern tradition, following the Creed of Jerusalem. (Shahe' arq. Atwe'mean 2001: 16) 
In the Armenian church two other Creeds are canonized and stored. The first is a brief creed, which is pronounced at baptism, after the "Renounce" and the second is the general Creed of Grigory of Tatev, which he presented in his book "The Book of Questions" within fourteen points, which also includes a summary of our faith. Creed is used before night Mass, after morning psalmody, and begins with the following words.

"Confess with Faith God the Father with entirely heart, who is not wicked, unbegotten and without beginning, but also is the parent of the Son and originator of the Holy Spirit..." (Shahe' arq. Atwe'mean 2001: 24)

This Creed must is uttered during the ordination after the oath.

The Creeds of Nicene and Gregory of Tatev are considered three-part as they involve parts concering the Father, Son and Holy soul.

The Fathers of Armenian Church starting from Saint Gregory the Illuminator have specifically emphasized the inseparable unity of devine and human nature of Christ,because they believed that the incarnate was the same God that was born in Saint Virgin,the same Christ,that was baptized, the same who preached and performed miracles, who suffered and was crucified, who resurrected and appeared to his apostles,and the same who should again come and renew the whole creation with the clear understanding that only God could be Saint Liturgy that must be sacrificed for the salvation of people. (Shahe' arq. Atwe'mean 2001: 24)

The creed in the Christian Church acquired great importance and it is deeply rooted in the hearts of Christian believers. Creed expresses the essence of God's nature, as well as the essence of St. Trinity, which is the foundation and major axis of Christianity. But along with it the key measure is the Faith for understanding the Creed in general and for grasping the essence of Christianity.

All in all, we can state that the Faith of Armenian Church is the Faith of Universal Christian Church, that was initially formulated in Nicene Ecumenical meeting and, later on, was confirmed in further meetings becoming acceptable for all churches till nowadays.

\section{REFERENCES}

Abbe Duchesne (1950), The Early history of the Church, vol. 2, London.

Astuac'ashunch (1994). (The Scripture), E'jmiac'in.

Kartashev, A.V. (1994). Vselenskie sobory (Ecumenical Councils), Moskva.

Kelli J.N.D. (1993). Early Christian Greeds, Singapor.

Kirakosyan, A. (2007). Erroedabanakan vetwery' III dari verjin (Trinity disputes at the end of 3 rd century), Er\&an.

Kniq hawatoy... (1914). (Seal of faith...), E'jmiac'in, (Ant'ilias, 2001).

Shahe' arq. Atwe'mean, (2001) Mer hawatqy' (Hawatoy Hanganak, Davananq Hay Ekeghecwoy) (Our faith (Creed of Faith, Creed of the Armenian Church)). E'jmiac'in. 